\title{
BODIES BECOMING PAIN: UNUSUAL STRATEGIES OF DISSENT IN SOME TRANSNATIONAL LATIN-AMERICAN WOMEN WRITERS
}

\author{
María Jesús Llarena Ascanio \\ Universidad de la Laguna \\ mllarena@ull.edu.es
}

Recibido: 21-12-2019

Aceptado: 22-03-2020

(c) $($ i)

\section{ABSTRACT}

This paper interprets the way in which transnational writers use monstrosity and the uncanny to investigate the concept of the HomeSpace with dissent. An important group of unusual creatures in the contemporary fiction of Latin American women authors seem to «crawl out of their skins» (Himani Bannerji). This essay tries to analyse these speculative narratives which we will call hemispheric and which bear some resemblance from the north to the south of the continent, for different political and traumatic reasons, focusing especially on their cinematic deployment of the HomeSpace horror, childhood memories and physical and psychological boundaries which chain us to our ancestors' memories. We will try to examine a range of subversive metamorphoses of the female body in recent speculative fiction by Cecilia Eudave, Socorro Venegas, Mariana Enríquez, Samanta Schweblin, Valeria Correa-Fiz, Florencia del Campo, Agustina Bazterrica or María Fernanda Ampuero. These writings could be read as poetical and political strategies of dissent that innovate within the genre of speculative fiction.

KEY WORDS: memory, the unusual, transnationalism, dissent, the neofantastic, monstrosity, the uncanny. 


\section{CUERPOS QUE REFLEJAN DOLOR: DISENSIÓN EN LA NARRATIVA DE LO INUSUAL EN ESCRITORAS TRANSNACIONALES LATINOAMERICANAS}

RESUMEN

Este artículo interpreta el modo en el que escritoras transnacionales usan lo monstruoso y lo ominoso para investigar el concepto del espacio doméstico con disensión. Un grupo importante de criaturas inusuales en la narrativa contemporánea latinoamericana «repta fuera de su piel» (Himani Bannerji). Este ensayo intenta analizar esas narrativas especulativas que llamaremos hemisféricas y que muestran semejanzas de norte a sur del continente americano, por diferentes razones políticas y traumáticas, especialmente en su expresión cinemática frente al horror en el espacio doméstico, en las memorias infantiles, y en las barreras físicas y psicológicas que nos encadenan a la memoria de nuestros antepasados. Trataremos de examinar algunas de las variantes de metamorfosis subversivas del cuerpo femenino en obras de Cecilia Eudave, Socorro Venegas, Mariana Enríquez, Samanta Schweblin, Valeria Correa-Fiz, Flor del Campo, Agustina Bazterrica o María Fernanda Ampuero. Sus obras podrían leerse como estrategias poéticas y políticas que innovan dentro del género de la ficción especulativa.

Palabras Clave: Memoria, lo inusual, transnacionalismo, disensión, lo neofantástico, monstruosidad, lo ominoso.

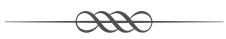

The object of prominent philosophical and critical attention in the last decades of the twentieth century are the theories of trauma and the posthuman, which have become key frameworks to approaching contemporary culture and its artifacts, which undermine key dualisms of the Western philosophical tradition. These posthuman tropes symbolically point to the ills of globalization, consumerism and late capitalism; they evoke the new conditions of traumatic enslavement under technoscience, offering some hope for ironic reformulation (Ferrández San Miguel, 2018: 31-32). These writers explore ways in which fantasy and elegy, among other generic modes, can come to terms with the contemplation of destruction, loneliness and death. We thus bear in mind questions about how reality is represented in fiction and how trauma is at odds with representation. What lies outside the explicable has been a predominant approach taken by trauma and witness studies, their main claim being that narrative is insufficient to express acute distress. These 
formulations, as Judith Butler has noticed, set «violence and language in opposition, as the inverse of each other» (1997: 6). In the 1990s, the definition of the violent traumatic event as a physical or psychological wound that exceeds our cognitive and linguistic capabilities derived in interpretations which focused on the drama produced by the impossibility of verbalising the effects of extreme violence. Language and narrative tried and failed to communicate properly (Hernáez-Lerena, 2019:146). Trauma is produced by acts of collective memory and it can be analysed as a cluster of texts, images and narratives that are instrumentalized by political and cultural institutions. Through stories, then, trauma is mobilised and ascribed a set of meanings, as well as a set of emotional reactions and, in these literary spaces, individuals live isolated lives in the aftermath of decisions taken in remote centres of power.

The following stories pay attention to the disjunctions within the subjective experience of the uncanny, in what Carmen Alemany has coined the unusual, a type of discourse which reflects real, explicit and contextual experiences, or what David Roas has defined as the neofantastic (2011: 38). According to Alemany, texts reflect collapsing routines and characters who do not find their place in the world (2019: 11). This displaced, hybrid and permeable discourse integrates any genre, and show stories where the real comes out in unusual situations, namely through metaphoric systems of representation, thus revealing hidden emotions that pervade our daily life. The uncanny defamiliarization becomes risky in its search for balance, sometimes deploying absurd, humorous or sinister tropes in its search for alternative worlds that show the cracks of the so called reality:

La etiqueta de «narrativa de lo inusual» nos permite amparar una literatura que se mueve en baremos no usuales, infrecuentes, pues no hay en sus ficciones una intencionalidad explícitamente fantástica, aunque sí la necesidad de acudir a otros parámetros que fluctúan en la franja que oscila entre lo real y lo insólito. (...) Una forma de ficción en la que prima la incertidumbre, aunque los hechos transcurran en el plano real con transiciones hacia lo onírico o lo delirante (...) analogías, metáforas, comparaciones, alegorías nos sirven para explicitar de otro modo lo real. (Alemany, 2016b: 114)

The Mexicans Cecilia Eudave and Socorro Venegas, and the Argentinians Samanta Schweblin, Mariana Enríquez, Florencia del Campo, Agustina Bazterrica or Valeria Correa-Fiz are clear examples of unusual storytelling which resort to body monstrosities and ironic allegories to express cultural or 
political dissent. We will try to analyse some transnational characteristics that define these writings, which we will consider hemispheric (Siemerling and Phillips Casteel, 2010) as they reveal connections among a broad range of American storytelling from north to south, challenging the convention that the study of this literature should be limited to its place within national borders. We argue that these works should be examined from their perspective of their place and influence within the Americas as a whole. This concept expands the horizons of American literatures, and suggests alternative approaches to models centred on the United States. Revealing the connections among a broad range of Canadian, Latin American, Caribbean and diasporic literatures, we believe such writing can be successfully integrated into an emerging area of literary enquiry. Globality thus reveals exciting new ways for thinking about transnationalism, border cultures, the uncanny and the gothic, which are linked to the paradox of home and unhomeliness.

This storytelling enacts ambivalence, offering a possibility of mediation into real-world politics, since it «exposes the Gothic reality of modern identity, and by failing to represent an adequate solution it forces its readers to address them in real life, thus (ideally) using literature to encourage social change» (Sugars and Turcotte, 2009: xv). The inherited gothic is then defamiliarized by being rendered reassuring and familiar. Even if the fracture that trauma provokes in our protagonists is usually read as negative, the self seeks for reintegration as the fragmentation and hybridization that result from the assimilation of the posthuman is potentially liberating. The gothic genre has traditionally provided conventions to represent shocking events: violence, slavery, power abuse, cruelty, inequality and so on. It creates a territory where the actual and the imaginary can meet and display a variety of resonant motifs, including burial, invasion, personality disruption, disease and entrapment, among others. Its codes are often studied on a par with trauma narratives because the gothic is an instrument of translation, a comparison model that, like any other genre, endows narratives with a certain amount of navigability. We expect the strange occurrences in the gothic to embody fears and anxieties, to flesh out historical breaches of the natural or desirable order of things. The potential of haunting as a trope for identity may operate within the unsettling atmosphere of traumatized homeSpace, but also within a more invigorating scenario where acceptance of the supernatural has positive implications, since, as Sugars implies (2011), it provides humanity with spiritual reparation and cultural sustenance, so the gothic is a genre that enables poetic justice (Hernáez-Lerena, 2019: 149-150). 
Paul Gilroy's conceptualizing of the black Atlantic has been particularly useful to relate to the work of Latin American theorists to produce a global and hemispheric approach to the literatures and cultures of the Americas. There is a culture that is not specifically African, American, Caribbean, or British, but all of these at once, a black Atlantic culture whose themes and techniques transcend ethnicity and nationality to produce something globally unknown before. This mode of storytelling is preoccupied with the fringes, the unspoken, the peripheral, and the cast aside. It is populated with monsters and outcasts, villains and victims, specters and the living dead. We will see how there is an American articulation of a transnational revisioning of their traumatic histories, to embrace their national meta-narratives, to articulate globality and to write back to nationalist paradigms in order to challenge dominant literary, political, and social narratives. We do want to advocate other approaches based on a global and hemispheric reframing of the origins, production, and concerns to look closely at how the production has increasingly become transnational, and how it has become engaged with a set of issues related to globalization (Jay, 2010: XI).

In Latin America this booming genre reflects a number of hybrid creatures who take centre stage in their narratives and are representative examples of «the posthuman predicament» of our times (Braidotti, 2016). While each of these writers draws on different cultural backgrounds and folklore for the creation of their neofantastic characters, they enable their readers to imagine new figures of queer posthuman hybridity. All participate in a common project that can be described as postcolonial, posthumanist, feminist, queer, and anti-imperialist, as Martín-Lucas suggests (2017: 152). This speculative fiction is a «hybrid blend of generic features» (Cuder-Domínguez, 2008: 117), which takes into account the history of the dispossessed, the displaced, the exiled, the migrant, the multitude, and insert new subvertive perspectives (Martín-Lucas, 2017: 154). Queer unhappiness in these bodies is a form of cultural dissidence as we read in Sara Ahmed (2010). As we resist the notion of «general will» or heteronormative «happiness», which functions as a potent instrument of social control, «the unhappiness of the deviant performs a claim for justice» (2009: 11). This claim for justice allows vulnerable characters to act as feminist killjoys in order to address injustice, to turn those memories of grief into something that is not only powerful but necessary for healing. As Eudave reflects in Bestiaria vida, «porque vivo asustada y porque creo que así viven todos. ¿Por qué pienso de esta manera? ¿Por qué no creer, un instante al menos, que existe un sinónimo de la transformación, de la regeneración, del cambio, de la locura como principio de otra vida?» (2018a: 97-98). 
The characters spend half of their life hunting for their «remorseful feelings» (2019a: 25-26), ghosts within ourselves, «no hay nada más extraño, incomprensible, paradójico, imposible, recóndito, insoportable, científico, profundo, infinito e interestelar que el espacio interior; es allí donde hay que explorar» (2018a: 109). This displaced character seems to underline the idea of the inexistence of happiness as such: «No sé por qué no puede haber ciclos de felicidad completa», claims the narrator, «[p]or qué el ir y venir entre la satisfacción, siempre pasajera, y la desilusión sanguijuela» (2018a: 54). As we read in Felisberto Hernández's «Las hortensias», artificial beings usually come to life in the homeSpace, ${ }^{1}$ either dolls, or the little women as in Solange Rodríguez Pappe's story (2019: 99-103), which recall the little selves living on the carpet in Bestiaria Vida. As Eudave asserts: «Lo enunciado lleva a plantearnos el espacio como un lugar privilegiado para el tránsito y desarrollo del horror desde los planos de la realidad representada» (2018b: 59). In Microcolapsos dolls are symbols of imposed beauty and innocence: «la inocencia prolongada, la ingenuidad perpetua, la bondad aparente no pueden ser otra cosa que la máscara de una perversa. Y a pesar de su cabellera rubia y su candor logré refundirla en lo más profundo del armario. Decidí esa misma noche que ni muñeca ni nadie deben vivir complaciendo los caprichos de una ilusión» (2019a: 37). Horror is, then, «una palabra que con solo pronunciarla pone en marcha toda una maquinaria de representaciones de orden moral, ético, religioso, económico, político que transgreden realidades o las prefiguran para crear espacios donde vamos de la desestabilización al apocalipsis de los valores establecidos y sus formas» (2018b: 58). The homeSpace is thus inhabited by fear, «[m]ejor seguir ignorando el miedo, aunque esté aquí, sentado en este mismo sillón, compartiendo sus proezas con los fantasmas que él me ha sembrado en el camino. Mejor seguir bajo el agua, sacando los ojos apenas como hacen los cocodrilos, sin olvidar el instinto de conservación para evitar el taconazo entre las cejas» (2018a: 56).

Eudave claims to live an abstract life where ideas are more precise than rules: «Te enseñan trucos como si fueras una pequeña bestia. (...) No eres de otro planeta, asúmelo, (...) vives entre objeciones — referenciales - no identificadas» (2019a: 53). In this domestic space, where «los miedos se heredan» (2018a: 50), liminality and space function as the trope of the nation-space.

1 «"Las Hortensias" se convierte en una de las nuevas formas de plasmar lo fantástico. A partir de entonces marcará no sólo la obra de de Felisberto Hernández, sino la de otros escritores que tomaron su lección - Italo Calvino, Julio Cortázar. Así la creación artificial, artística, finalmente, absorberá la realidad, y la hará formar parte de ella. La inversión entre los órdenes no sólo se manifiesta entre lo artificial y natural, sino también entre lo animado e inanimado. Todo ello, a pesar del ambiente onírico, de juego fantástico» (Morales, 2004: 154-155). 
Ahmed's The Promise of Happiness (2010) explains how we have inherited a long lasting perversity: «Ahora el Edén se ha diversificado en sociedades que tienen sus Evas y sus Liliths; saben, ya somos amigas, nos vamos conociendo, respetando, y hacemos frente a los mismos Adanes; esos que cuando llega el viernes de bares, o salen de fiesta, ven en cualquier mujer un demonio al que deben someter» (2019a: 61). Writing, for Eudave, brings a promise, a mental and physical fright regarding the human condition:

una narrativa de índole personal que experimenta episodios esquizoides, desdoblamientos y elucubraciones y que se manifiesta desde la subjetividad. (...) En este tipo de textos se refleja una realidad cotidiana accidentada y abrupta en la que los personajes no encuentran su ligar en el mundo. Y como fruto de nuestro tiempo, se trata de un discurso híbrido y permeable (...) que oscila entre las fronteras de lo fantástico y lo real difuminándose los límites. (...) en Bestiaria vida, no hay una intencionalidad explícitamente fantástica, aunque sí la necesidad de acudir a otros parámetros que fluctúan en esa franja que oscila entre lo real y lo fantástico pero que termina por detenerse en lo primero. (...) Mundos inusuales que son sistemas de representación metafórica y que intentan revelar las emociones ocultas detrás de las circunstancias cotidianas. La narrativa de lo inusual vendría a ser una mezcla híbrida de la representación de la realidad tradicional y una realidad insólita, su síntesis. (...) un péndulo que oscila entre lo insólito y la realidad convencional o convenida. Ahora bien, (...) en los textos inusuales lo fantástico está al servicio de lo real. (Alemany, 2018: 10-11)

In Eudave the irruption of extreme grief makes the characters' power for reasoning falter: «lo desolados que estamos, pues nadie te dirá en donde hallarte, porque no hay a quién preguntarle, ni siquiera a ti mismo» (2018a: 95). The literary strategies that keep these characters' ordeals in a perpetual present in our mind are the compelling language and 'alter-narratives' that their subjectivities create - submerged stories that are triggered by a realization of life's opacity: «Vivimos en medio de fábulas, cuentos y dramas, somos personajes sin quererlo de las demás historias, las que alguien algún día contará como las suyas, aunque también sean nuestras» (2018a: 102). These emotional predicaments show to various degrees the characters' loyalty to that uninterpretable strangeness: «¿Cómo se puede recordar? Pasan los acontecimientos tán rápido, tan sin tomarnos en cuenta, el tiempo nos juega siempre malas pasadas, y se lleva lo tuyo, allá, donde el pasado esconde lo inútil» (2018a: 28). In Eudave, as the Mexican writer Amparo Dávila did in her story «El Huésped», the uncanny homeSpace turns into a fearful space: «un espacio ordinario que se pervierte y que es reemplazado por otro de apariencia 
fantástica con el fin de propiciar el estado extrasensorial de los personajes, reforzando el horror, no a lo desconocido sino a aquello real que presentimos como una amenaza» (2018b: 65). The family space is monstrous and the sense of unhomeliness is recurrent, and can only be shown through hybrid cultures who dissent heteronormative happiness:

Y desde ese momento decidí que esa niña era un monstruo, un demonio, de esos que son así como son: abominables, rasgo destacado en su personalidad. Solo tenía que precisar bien a qué clase de monstruo o demonio pertenecía. Resultó ser una Súcubo y con el tiempo se confirmó. Pues cuando su maldad dejó de concentrarse en mí (...) fue para centrarse en un montón de infelices a los que les destrozó la vida. Ojalá yo hubiera estado tan segura de mi como lo estaba de ella. Pero no, no tenía la menor idea de quién era yo, ni por qué estaba allí. Y volví a enrollarme en la cama mientras la Súcu crecía y crecía. (...) Sí, así veo a mi familia, como un minotauro, como un laberinto, como a bestias que resguardan su centro, y yo debo vencerlas para salir, para olvidar, para vivir. (2018a: 31-33)

This contextual broadening makes the homeSpace function as both a site of identity construction and performance and emancipation, a site of disruption, resistance, and alienation (Diana Brydon 2017: 6). One important focus lies in this alienation towards the monstrous mother and her mental disability:

Mi madre fue mutando varias veces hasta revelar su verdadera personalidad. Cuando yo era una niña, ella oscilaba entre "Fiera malvada", una especie de ser monstruoso y fantástico sin aspecto fijo (...) y un Basilisco por su extraordinario poder de matar con la mirada. Cómo miraba mi madre. Debía cuidarse mucho al pasar frente a los espejos. Si ella llegaba a verse a sí misma como nos miraba a nosotros, seguro ahora estaría muerta, y no en ese mutismo en el cual se ha encerrado, inmersa en sí y solo para sí. (2018a: 34)

Alzheimer and other kind of mental disorders appear as an explanation of the physical impotence of the unwilful subject, isolated, unable to dissent:

Si existe un limbo, es allí, donde mi madre habita. (...) Esa es la imagen que me viene cuando la veo sentada en sí misma, en medio de ese limbo tan blanco, rodeado de enfermeras disciplentes que nos sonríen con lástima, con la compasión del que cuida al monstruo de los otros. (...) Me meto en el baño y vomito. Luego salgo como si nada, disimulando, fingiendo lo contenta que estoy de ver a mi madre ida, con los ojos hundidos y la piel amarilla, con los huesos pegados al pellejo, hablando un soliloquio que nadie entiende lleno de números y de palabras incompletas. (2018a: 111-112) 
The mediating function of environmental advocacy turns our visions of the fantastic into a catalyst for social action and cultural dissent: «estoy sola otra vez en un piso entre selva y ruinas. Recordando. Es vicioso de mi parte hacerlo, pues evito contacto con el exterior para concentrarme en lo que he ido acumulando en este caparazón de caracol, pero qué se le va hacer, los tormentos nunca van a desahogarse al mar» (2018a: 111). In Eudave's «De natura» the garden becomes an ominous paradise whose trees produce human creatures which reveal this environmental dehumanization: «Comenzó a percibir el fruto en marzo, como estaba previsto, del que empezaron a aparecer unos pies muy finos. (...) En abril el cuerpo ya estaba formado, en mayo nació una hermosa cabeza de rostro impecable y durante junio creció hasta convertirse en una adolescente perfecta que se desprendió y cayó al suelo gritando 'wakwak'. (...) Murió a los pocos minutos de desprenderse del árbol” (2019a: 65). In Socorro Venegas's stories La memoria donde ardia, maternity, the absent father, and their paralized children also try to survive the homeSpace. The painful scars are the most important trope to be examined in creating an emotional territory. Venegas's characters reflect painful bodies, they become pain and see life from that fearful perspective where characters are survivors, liminal creatures who try to deviate from heteronormative positions in society:

Dormido, acurrucado contra la pared, ahí en la calle, estaba su padre. Andrea sintió mucha vergüenza, ¿qué pasaría si alguien de la escuela la reconocía? Vio que a través de la botella ya no se deformaban las cosas: estaba vacía. No importaba, no volverían. Se sentó a su lado. Subió a su nariz el olor a orines y alcohol secos, una sensación de asco la hizo arquearse. (...) ¿Para qué ir a casa? No se separaría de su papá. (...) Su padre estaba sentado en la orilla de la acera, y para ella era un gigante que soñaba, un destructor, un coloso triste. (2019: 20)

Both Venegas and Eudave share the organic experience of the homeSpace as hell. The space of maternity is hostile territory:

Me llevo las manos al vientre: un hueco, ahí donde el pequeño creció hasta el día del alumbramento. Sí, el fantasma del dolor, eso que me impide dormir. (...) No sabía qué era ser madre, hasta ese momento. El dolor me rompe en el centro, un dolor sin orillas. Mis huesos se abren, los pulmones explotan, me posee el aroma de la sangre. El grito se queda adentro, donde más daño hace, donde nunca tendrá reposo $(2019: 75,105)$.

Venegas's toxic trauma is made of absence, of the sudden dead body of the young husband found lying dead on the floor of the bathroom: 
Un ser mutilado no es más un individuo. (...) Y el mundo era otro. Sucedió en unos instantes. Cuando entré en el baño pensé que bromeabas. Que fingías haberte desmayado. Me quedé inmóvil en el umbral. Tu cuerpo desnudo, tan blanco. (...) Un remolino furioso irrumpió en esa casa que éramos nosotros mismos (...) me parece extraño que el espejo no muestre nada del cansancio que arrastro. (...) Insólito no parecer más vieja. (...) Y yo sin saber qué hacer con mi vida por delante. (...) Qué cara ponerle a nuestros muertos. (2019: 104-106)

This intermediateness, represented by the questioning of what is real and what is unreal, is ultimately strengthened by the use of space, as in the claustrophobic rooms in Bestiaria vida, in del Campo's basement in La huésped (2016), or Correa Fiz's «Una casa en las afueras», in La condición animal (2016). As we learnt in Amparo Dávila «El Huésped» or Julio Cortázar's «Casa tomada», this unusual use of the supernatural emerges in real spaces, turning comfort zones for characters into monstrous spaces to take refuge from the ugliness of the material world. As the narrator in La huésped claims, «[c]amino y con cada pisada siento que doy un martillazo. Hay que romper todo: todo está lleno de bichos, no es solo azulejos y baño. Es todo. Lleno de bichos y mierda. Esto se ha contaminado» (2016: 83).

Ideas about journeying in the Argentinian dictatorship in the eighties, the depictions of the road trip in Enríquez's Nuestra parte de noche (2019b), or the family space in Ese verano a oscuras (2019a) show that the liminal spatiality is integrally associated with the influence of other American stories, such as Cormac McCarthy's The Road and the English Gothic, where home is a space of visible absence: «No recuerdo demasiado a los padres ese verano, salvo al mío con sus explicaciones de lo inexplicable. Los demás o estaban buscando trabajo o estaban deprimidos en la cama o tomando vino frente al televisor apagado o en algún consulado intentando conseguir una ciudadanía europea para escaparse, cualquier ciudadanía europea, si era italiana o española mucho mejor» (2019a: 11). In Ese verano a oscuras we read: «No había bastante muerte ya, acaso, decían, hablaban de la dictadura y los torturadores; no entendían que a Virginia y a mí nos gustaba otro tipo de infierno, un infierno irreal y ruidoso, uno de máscaras y motosierras, de pentagramas pintados con sangre en la pared y cabezas guardadas en la heladera» (2019a: 20). These violent scenes use metaphor to show women's vulnerability and precarity in different parts of the world, in a frightening cosmopolitanism, to express the dehumanization of current society:

La nena ya estaba muerta cuando su padre la colgó. La había apuñalado varias veces con un cuchillo distinto al que había usado con su madre - uno pequeño 
de cocina, común, doméstico- - y la dejó desangrarse en el piso del comedor. Después la ató a la ventana de la habitación, como si se tratara de una bandera o una muñeca. La ató de una manera compleja, con un nudo que pasaba bajo sus axilas y se cerraba sobre el cuello. Estuvo colgada así, durante la noche poco más de una hora. De no ser por el cigarrillo y la angustia del hermano de Pity, hubiera amanecido muerta y colgando, con el pelo color chocolate ardiendo bajo el sol. (2019a: 49)

In Cadáver exquisito (2018), a mortal virus has vanished animal life and cannibalism is legalized to solve other problems, such as overpopulation and poverty. According to the government, a virus has made animal meat untouchable, and human meat, 'special meat', is now sanctioned. Marcos runs a factory that raises and slaughters humans, and is intimately involved with every stage of production. Marcos supplies butchers, tanneries, laboratories, even a mysterious game reserve, and is our tour guide through the horrors. He is a man in shock not just at the undeniably unusual new reality, but at the loss of his young son. His father is sinking into dementia in a nursing home; his grieving wife has retreated to her mother's; his sister is a shallow social climber. The biggest existential wound, however, is the loss of animals since they were eliminated to halt the spread of the virus. Beings are called 'heads' in an effort to dehumanize the process, their vocal chords removed so they can't scream, kept naked and tied up in processing plants. They are graded into 'First Generation Pure' and branded on their forehead with their status.

The eerie, depopulated landscape is reminiscent of another intensely effective Argentinian shocker, Samanta Schweblin's Distancia de rescate (2014), a novella inspired by fears of environmental degradation but, here, the critique of carnivorousness is obvious. Bazterrica draws on the conventions of horror in this dystopian novel that takes the ultimate taboo, cannibalism. However, Marcos's main obsession is not flesh but language: how we construct the world out of words, how we speak the unspeakable, and how we negotiate the gap between words and reality. If this is a fable about the inadequacy of language in the face of darkness, it also resonates with sadness at the prospect of silence humans can expect when we are alone in the world, in the wake of mass extinctions (Jordan, 2020). It may also depict a solution to the future food dilemma, becoming scarily realistic, painful and disconcerting. Not just for the flesh-eating theme but for the echoes of othering, of slavery, of racism, which blight out modern societies. Beings are dehumanized by stealing their voices, denying them any rights, making them property, reinventing the language that accompanies their abuse (Burke, 2020). With reminiscences 
of Orwell's 1984, Huxley's A Happy World or even Atwood's The Testaments, humans become zombies and phantom bodies (García Zarranz, 2013). Cannibalism thus stands for carnivory, both part of the same process, the eating or consumption of another's flesh (Huggan and Tiffin, 2010: 175). Most human meat eating is ultimately an expression of power over others, in particular women, animals and the poor. As Carol Adams asserts, meat eating is interwoven with various forms - violent forms - of sexism and anthropocentrism, while there is evidence to suggest that as individuals within communities, or communities themselves, become wealthier a dietary shift from vegetarianism to carnivory occurs (2010: 176). Carnivory is also an expression of the power to dictate the categories of 'edible' and 'inedible' and a potent symbol in the discourse of 'othering' —on which many human communities are reluctant to relinquish even at the expense of preserving the planet itself (2010: 178).

Toxic traumas also appear in Ampuero's Pelea de gallos, where violence and abuse are part of the protagonist's childhood memories: «te golpeaban para que no fueras igual a tu madre mientras te gritaban eres igual a tu madre» (2017: 64). This violence is born in the child abuse and the parental silence, hiding some monstrous secret that needs to be unveiled: «Sé que aquí, en algún lado, hay gallos, porque reconocería ese olor a miles de kilómetros. El olor de mi vida, el olor de mi padre. Huele a sangre, a hombre, a caca, a licor barato, a sudor agrio y a grasa industrial» (2017: 12). We are dealing with painful and monstrous bodies: «creo que abrazar tu monstruosidad, aquella monstruosidad que tienes y que te critican, la monstruosidad por la cual no calzas, podría ser en parte lo que hace que mis personajes sobrevivan. Sobreponerse al dolor es, en gran parte, seguir adelante» (Cavallín, 2019).

We are troubled creatures whose experiences of embodiment and corporeality are depicted in terms of lack, trauma, and fear: «No tener cuerpo es un deseo errado. La piel, la carne cuentan; son como un palimpsesto donde se inscribe nuestra historia», we read in Correa Fiz (2016: 106). As in Bazterrica's Cadáver exquisito, by using the trope of skin as a permeable border, they propose fluid transgender, transexual, transnational, trans-species modes of what has been theorized as «deterritorialized citizenship» (Martín-Lucas, 2012), that is, of being a civilian (whether human, cyborg, alien, or cannibal) related to others in diverse social forms of kinship and community not dependent on land, tribe or citizenship that have traditionally defined national belonging (2012: 124). As Ampuero asserts in her dissenting voice as a perpetual killjoy: «como monstrua voy a sobrevivirte. Voy a sobrevivir a tu daño, voy a sobrevivir a tus palabras, voy a sobrevivir a tus prejuicios, a tu violencia, a tu bully- 
ing, a tus ganas de destruirme» (Cavallín, 2019). The homeSpace is, in Pelea de gallos, a place where the Stockholm syndrome pervades our childhood, where secrets are kept hidden to avoid public shame:

La institución más gordofóbica, homofóbica, racista, clasista, xenofóbica, es la familia. Hay que hablar de esos adultos destructores y destruidos; hay que hablar de la institución, de la maternidad, como algo que fácilmente puede volverse perverso. Creo que no hay nada más profundo que el daño que te puede causar la familia. Eres heredera de un mal que se gestó hace años. Me ha gustado hiperbolizarlo todo, la abyección, el incesto, para que el daño de la familia tuviese una lupa gigante. (Cavallín, 2019)

The use of the first person is born in painful memories, in private territory. The decentring of the female subjects and of female agency, this emphasis on survival, evokes Butler's interest in the concept of liveability. Some lives become recognized, and thus liveable, while other lives are marginalized and abjected (Schippers, 2014: 3). Butler positions the subject as relational, the connection, or ties, we have with others constitutes our sense of self (2004a: 20). In Undoing Gender, we read, «[d]espite all our differences in location and history, my guess is that it is possible to appeal for a 'we', for all of us have some notion of what it is to have lost somebody. Loss has made a tenuous 'we' of us all» (2004a: 20). Florencia del Campo also shows how identity is thus involved in corporeal changes, and sickness gives way to the questioning of our liminal subjectivity and our permanent feeling of the family menace of making us feel monstrous. Mental and physical disease triggers our thoughts towards identity processes and depict other ways of naming the narrative experience, to analyse different forms of seeing ourselves as other: «Who counts as human? Whose lives count as lives? And, finally, what makes for a grievable life?» Butler wonders (2004b: 20). Flor del Campo adds the fact of the pain and guilt of being a woman-carer who suffers the pain, who is demanded to renounce to being female, wife or daughter. Showing the hospital documents within the fictional experiment, goes beyond in its parody of objectivity and reliability in madre mía, whose narrator wonders whether the bed-ridden sick mother is a manipulating monster: «La familia puede ser a la persona lo que un tumor al cuerpo» (2017: 171).

The very definition of humanity and globality depends on both the construction and the exclusion of the non-human, the uncivilized, the savage, the animal. Huggan and Tiffin call for a revision of the Humanistic world view: «The key issue is no social justice without environmental justice; and 
without social justice — for all ecological beings— no justice at all» (2015: 10). These are the resources hemispheric storytelling use to turn displacement and ostranenie into an ordinary family tragedy, developing an aesthetics of the neofantastic based on the limited viewpoint of an ordinary narrator-protagonist who observes how everyday objects reflect an unusual reality. These literary attempts at remembering are important cultural interventions of dissent: «Personajes imaginando lo que recuerdan, recordando lo que imaginan. ¿Es verdad? ¿Es mentira? No son esas las preguntas» (Neuman, 2014: 23). The question, and answer, lies, for Drucaroff, deeply rooted in a number of «thematic staines» (2011: 488) when dealing with displacement, the monstrosity of the disappearance and torture, the «filicide imaginary», or the false memory in their endless search for footprints to unveil their recent past traumas. Short stories by Schweblin (2015), Correa Fiz (2016), Enríquez (2017), or Drucaroff (2019) have all helped to disrupt the silence that had previously prevented an international awareness and a public denunciation of such a tragic period of Argentine history. They are linked together by commonly denouncing the silence and searching for an identity to represent the extent of human suffering in a world that denies them their very humanity (Lubarsky, 1997: 41-42).

What Elsa Drucaroff terms «New Argentinian Narrative» (2011: 95) analyzes the renaming of the silenced trauma of the generation of writers born in the 60s and 70s: «Una narrativa verdaderamente nueva y, en muchos casos, valiosa, además de un movimiento dinámico y crítico de la sociedad argentina» (2011: 185). Their writing of dissent, of renaming the past is political in its metaphorical deployment of historical trauma, «es interesante subrayar la simbólica mención -y aceptación de la existencia- de un trauma político, tanto en su vertiente colectiva o nacional como en el aspecto personal o familiar», Neuman says (2006: 4). As Ana María Shua puts it, «una de las formas que adopta la memoria (del pasado reciente) es un género que, aunque reconoce raíces en nuestra tradición, trae también una novedad muy importante: es la narrativa del horror» (qtd. in Drucaroff, 2011: 296). Rahul K. Gairola also analyses these malevolent spirits as «otherworldly duppies» or spectres of dissent (2017: 19), posthuman bodies which are contaminated, deadly, queer bodies. In Correa Fiz's «Leviatán» bodies disappear and Narcissus reflects a monstrous picture: «Se asomó al espejo del agua y una arcada le hizo verificar la pesadilla: los peces estaban disputándose un trozo de carne. En el centro del pozo resplandecía un brazo blanco. Vomitó, cayó de espaldas, se fisuró un tobillo. Dijo que creía haber perdido el conocimiento hasta la medianoche» (2016: 141). The HomeSpace turns glocal and serves as a repository of 
the Argentinian past, deploying cobwebbed memories even though it is materially, and territorially, anchored in the present: «Adentro el fuego, afuera la nieve, el cuerpo adentro, la mirada afuera» (Del Campo, 2016: 89). Mental or physical disease in the homeSpace also appear in Schweblin $(2014,2015)$ and Enríquez (2019) as a resource to question self-consciousness of our no-place in the world, a physical or psychological dislocation where malevolent spirits appear as spectres of dissent. The voice and tone which appear in Schweblin's Distancia de rescate and Enríquez's Nuestra parte de noche destabilize, in the countryhouse, the very notion of a national identity as an organizing principle of citizenship through a godlike Darkness. Spectral presences flush out the queer and tragic selves that circulate these narratives through persistent hauntings. Enríquez, Schweblin or Correa-Fiz pose a critique of how contemporary societies are populated by troubled creatures whose experiences of embodiment and corporeality are depicted in terms of lack, trauma and fear.

Over the last two decades Argentina's rural communities have reported skyrocketing rates of birth abnormalities, miscarriages and cancer. In the same period, genetically modified soy has blanketed the region. This is the agrotoxic landscape in which Samanta Schweblin's unsettling novella Distancia de rescate unfolds. Schweblin writes in a spare and highly impressionistic style that embraces instability: of space, identity and the reader's trust. It is a deeply transnational work, about parental love, rapacious industrial agriculture and historic trauma, whose narrative instability viscerally recreates the insecurities of life in Argentine countryside today:

El curanderismo, las seudociencias, la cultura new age, los rituales y saberes rurales sustituyen a la medicina y otros conocimientos científicos propiamente dichos. También permiten introducir un componente sutilmente fantástico y el terror (...) la separación cuerpo-espíritu y la transmigración de las almas daría como resultado una nueva criatura como única posibilidad de salvación en un campo manipulado por la transgénesis (De Leone, 2017: 69).

Schweblin, as Enríquez, does blur the boundaries between the natural and ethereal worlds in everyday life experiences of nature: «Schweblin pone en crisis imaginarios transitados sobre maternidades, como los del instinto, el deseo, la abnegación, la incondicionalidad y la procreación genética» (De Leone 2019: 72).

In Samanta Schweblin's Kentukis (2018) technological devices replace loneliness in the HomeSpace - as a reflection and metaphor of the nationSpace - and are connected to voyeurs, or civilian cyborgs, who are «reduced to 
acting out rational, pragmatic, instrumental behaviours (...) through the use of both technological and biological enhancement» (Critical Art Ensemble: 2930). Schweblin's message of dissent with Kentukis is obvious to express our vulnerability regarding technological toys, which may connect to an anonymous voyeur in any part of the world. What is revealed is the fright to unclose our privacy, our trust on others and our exposure to a fake reality which, again, depict how humans manipulate technology and defamiliarize real communication. As she asserts:

Desde hace muchas generaciones pensamos la tecnología como este mal gigantesco pensante. La Inteligencia Artificial, un Gobierno supremo, una mega empresa. (...) No digo que eso no vaya a pasar, pero hoy por hoy ese mal no está en la tecnología en sí, sino que está en el otro. (...) Me fascina cómo la gente se toma la novela como algo de ciencia ficción, cuando todo lo que sale puede puede ser real, la tecnología ya existe (Morla, 2018).

Fiction becomes here a mirror of a sick society, a de-centering of the human, nurtured by scientific developments and its close relation to organic and non-organic selves. In Schweblin's Kentukis, the figure of the cloned cyborg can be more clearly understood in relation to Braidotti's reflections on the cyborg as an embodiment of resistance: «the cyborg as an embodied and socially embedded human subject (...) is rather a multi-layered, complex and internally differentiated subject. Cyborgs today would include for me as much the under-paid, exploited labour of women and children on off-shore production plants (...) who interface with computer technologies at post-human levels of speed and simultaneity» (2002: 18). Developing from Donna Haraway's view of Asian women workers as «real-life cyborgs», doubly alienated, «disassembled, reassembled, exploited as a reserve labor force» (1991: 133), these characters depict a resistant community similar to those predominant in the narratives by Schweblin or Bazterrica.

This alternative mode of social vinculation, explains Martín-Lucas (2012: 114-15), constitutes an important act of resistance to neo-liberalism since «allowing the extended family to continue offers individuals participating in that institution a social and economic power base which gives them the opportunity to refuse corporate culture. In addition, it creates a social process that has the potential to be more satisfying than participation in consumption processes» (Critical Art Ensemble: 122-123). Similarly, Haraway defines «kinship» as a relation based not on blood but on affinities and affect; in the post-human age, when she asks: 
Who are my kin in this odd world of promising monsters, vampires, surrogates, living tools, and aliens? How are natural kinds identified in the realms of technoscience? What kinds of crossings and offspring count as legitimate and illegitimate, to whom and at what cost? Who are my familiars, my siblings, and what kind of livable world are we trying to build? (qtd. in Winnburst 2003: 13).

The renewed interest in this classic gothic character resides, for Martín-Lucas, in its potential as a figure of subversion (2012: 118), since «the figure of the vampire, as metaphor, can tell us about sexuality, of course, and about power; it can also inscribe more specific contemporary concerns, such as relations of power and alienation, attitudes towards illness, and the definition of evil at the end of an unprecedentedly secular century» (Gordon and Hollinger, 1997: 3). All these metamorphoses and hybrid characters, as we see in Enríquez's characters, Adela and Juan (2019b), posit a challenge to stable and fixed characterizations of identity by resorting —in diverse and specific ways that rely on different cultural backgrounds - to the over-exploitation of dominant constructions of the monstrous Other. In Enríquez's texts, these narratives present figures of excess that transgress and overflow borders, racial, sexual, national, even supernatural, making normalcy limits and expectations explode (Fernández, 2019). These actors envision diverse forms of crippling and skin-stripping as enactments of resistance. At this point, there are obvious connections between the trope of the monstrous Other and theories of the abject, abnormality, and alienness in relation to both femininity and to the symbolic constructions of the nation. The monstrous, that is, the alien, is marginalized and repressed into the «not belonging», as a disgusting abject (Martín-Lucas, 2012: 119-120). The body becomes an important metaphor and site for intervention in the discourses on nationalisms, and it is on the body that these women writers inscribe their politics of difference, kinship, and affection. The monster, the freak, the alien, the mutant, the grotesque, have all been read as metaphors that problematize the diverse politics of exclusion/ inclusion. Therefore, these global, gothic discourses have «for some time been paired in critical invocations of the unhomely or spectral legacies of imperialism and globalization». As Sugars and Turcotte claim: «This legacy, which appears in the form of unresolved memory traces and occluded histories resulting from the experience of colonial oppression, diasporic migration or national consolidation, is readily figured in the form of ghosts or monsters that 'haunt' the nation/subject from without and within» (2009: VII). Therefore, these writers destabilize the physical world shattering the notion of safe space. Our space is haunted by uncanny characters, ghostlike figures of our 
past. We live on land we cannot trust: families are destroyed, motherhood is frustrated, an aura of psychological menace and otherworldly reality surrounds us. This ethical and transnational turn that we have been witnessing in the last twenty years has come to dominate the contemporary global fiction and reshaped it as what can be considered the New American Narrative.

\section{WORKS CITED}

Adams, Carol J. (1990): The Sexual Politics of Meat: A Feminist-Vegetarian Critical Theory, Continuum, New York. <https: / / doi.org/10.5040/9781501312861>

Ahmed, Sara (2004a): Willful Subjects, Duke University Press, Durham and London. $<$ https:/ / doi.org/10.1215/9780822376101>.

— (2004b): «The Contingency of Pain», The Cultural Politics of Emotion. Edinburgh University Press, Edinburgh, pp. 20-41.

- (2010): The Promise of Happiness, Duke University Press, Durham, NC.

- (2018): Vivir una vida feminista, trans. María Enguix, Bellaterra, Barcelona.

Alemany Bay, Carmen (2016a): «Narrar lo inusual: Bestiaria Vida de Cecilia Eudave y El animal sobre la piedra de Daniela Tarazona», Romance Notes, vol. 56, no. 1, pp. 131-41. <https: / / doi.org/10.1353/rmc.2016.0013>

— (2016b): «Bestiaria vida, de Cecilia Eudave: novela corta, novela de laberintos, novela de lo inusual», Revista de Literatura Mexicana Contemporánea, 68, mayo-agosto, 23:68, pp. 103-118.

- (2018): «Prólogo», en Cecilia Eudave, Bestiaria vida, Eolas ediciones, León, pp. 7-21.

— (2019): «Prólogo», en Cecilia Eudave, Microcolapsos, Eolas Ediciones, León, pp. 7-19.

Ampuero, María Fernanda (2017): Pelea de gallos, Páginas de Espuma, Madrid.

Atwood, Margaret (2029): The Testaments, Doubleday, New York.

BANNERJI, Himani (2000): The Dark Side of the Nation: Essays on Multiculturalism, Nationalism and Gender, Canadian Scholars' Press, Toronto.

BAzTerricA, Agustina (2018): Cadáver Exquisito, Alfaguara, Barcelona.

- (2020): Tender is the Flesh, trans. Sarah Moses, Pushkin Press, London.

BraidotTI, Rosi (1997): «Mothers, Monsters and Machines», en Katie Conboy, Nadia Median, and Sara Stanbury (eds.), Writing on the Body, Female Embodiment and Feminist Theory, Columbia UP, New York, pp. 59-79.

- (2002): Metamorphoses: Towards a Materialist Theory of Becoming, Polity, Cambridge.

-, and Paul Gilroy (2016): Conflicting Humanities. Bloomsbury, London.

BRYDON, Diana (2017): «Introduction. Canada, Brazil and Beyond: Extending the Dialogue», Canada and Beyond: A Journal of Canadian Literary and Cultural Studies, vol 2, no. 6, pp. 3-8. <https:/ / doi.org/10.33776/ candb.v6i1.3075>

BuRKe, Paul (2020): «Tender is the Flesh by Agustina Bazterrica», disponible en <https: / / nbmagazine.co.uk/ tender-is-the-flesh-by-agustina-bazterrica/> [12/03/2019]. 
Bodies becoming pain: unusual strategies of dissent in some transnational latin-american women writers

Butler, Judith (1997): Excitable Speech: A Politics of the Performative, Routledge, New York and London. <https: / / doi.org/10.4324/9780203948682>

- (2004a): Undoing Gender, Routledge, New York. <https:// doi.org/10.4324/ 9780203499627>

— (2004b): Precarious Life: The Powers of Mourning and Violence, Verso, London and New York.

CAvallín, Claudia (2019): «La existencia de la alegría más extraña: Entrevista con María Fernanda Ampuero», disponible en <www.latinamericanliteraturetoday.org/es / 2019/ noviembre / la-existencia-de-la-alegria-más-extraña-entrevista-conmaría-fernanda-ampuero $>$ [12/04/2019].

Cohen, Robin (2007): «Creolization and Diaspora: The Cultural Politics of Divergence and Some Convergence», en Gloria Totoricagüena (ed.), Opportunity Structures in Diaspora Relations: Comparisons in Contemporary Multi-Level Politics of Diaspora and Transnational Identity, University of Nevada Press, Reno, pp. 1-27.

Correa Fiz, Valeria (2016): La condición animal, Páginas de Espuma, Madrid.

CortázAr, Julio (1951): «Casa tomada», en Bestiario, Editorial Sudamericana, Buenos Aires.

Critical Art Ensemble (1998): Flesh Machine: Cyborgs, Designer Babies, and New Eugeni Consciousness, Autonomedia, New York.

Cuder-Domínguez, Pilar (2008): «The Politics of Gender and Genre in Asian Canadian Women's Speculative Fiction: Hiromi Goto and Larissa Lai», en Eleanor Ty and Christl Verduyn (eds.), Asian Canadian Writing Beyond Autoethnography, Wilfrid Laurier U., Waterloo, pp. 115-131.

Darias-Beautell, Eva (ed.) (2012): Unruly Penelopes and the Ghosts, Wilfrid Lauries UP, Warterloo.

DÁvila, Amparo (2019): «El Huésped» (1928), en Teresa López Pellisa and Ricard Ruíz Garzón (eds.), Insólitas: Narradoras de lo fantástico en Latinoamérica y España, Páginas de Espuma, Madrid, pp. 301-307.

Del CAmpo, Florencia (2016): La huésped, Base, Barcelona.

- (2017): Madre mía, Caballo de Troya, Barcelona.

De Leone, Lucía (2017): «Campos que matan. Espacios, tiempos y narración en Distancia de rescate de Samanta Schweblin», $452^{\circ}$ F, vol. 16, pp. 62-76.

DRUCAROFF, Elsa (2011): Los prisioneros de la torre: politica, relatos y jóvenes en las postdictadura, Emecé, Buenos Aires.

- (2019): Checkpoint, Páginas de Espuma, Madrid.

EnRíleuez, Mariana (2017): Los peligros de fumar en la cama (2009), Anagrama, Barcelona.

- (2016): Las cosas que perdimos en el fuego, Anagrama, Barcelona.

- (2019a): Ese verano a oscuras, Páginas de Espuma, Madrid.

- (2019b): Nuestra parte de noche, Anagrama, Barcelona.

— (2019c): «La casa de Adela», en Teresa López-Pellisa and Ricard Ruíz Garzón (eds.), Insólitas. Narradoras de lo fantástico en Latinoamérica y España, Páginas de Espuma, Madrid, pp. 39-54.

EudAve, Cecilia (2018a): Bestiaria vida, Eolas ediciones, León.

— (2018b): «Hacia una clasificación del espacio en textos de horror fantástico», Brumal. 
Revista de Investigación sobre lo Fantástico, vol. VI, no. 2 (otoño/autumn), pp. 57-73. <https: / / doi.org/10.5565/ rev/ brumal.507>

- (2019a): Microcolapsos, Eolas Ediciones, León.

- (2019b): «Sin reclamo», en Teresa López-Pellisa and Ricard Ruíz Garzón (eds.), Insólitas. Narrativas de lo fantástico en Latinoamérica y España, Páginas de Espuma, Madrid, pp. 17-25.

FERNÁNDEZ, Laura (2019): «Mariana Enríquez gana el Herralde con una novela 'monstruo'» disponible en <https:/ / elpais.com/cultura/2019/11/4/actualidad/ 1572864999_523113.html.> [12/05/2019].

FERRÁNDEZ SAn Miguel, María (2018): «Appropriated Bodies: Trauma, Biopower and the Posthuman in Octavia Butler's ‘Bloodchild' and James Tiptree, Jr.'s 'The Girl Who Was Plugged in'», Atlantis: Journal of the Spanish Association of Anglo-American Studies, vol. 40, no. 2, pp. 27-44. <https:/ / doi.org/10.28914/ atlantis-2018-40.2.02>

Gairola, Rahul K. (2017): «Bastardly Duppies and Dastardly Dykes: Queer Sexuality and the Supernatural in Michelle Cliff's Abeng and Shani Mootoo's Cereus Blooms at Night», Wagadu: A Journal of Transnational Women's and Gender Studies, vol. 18, pp. 19-54.

García PeÑa, Lilia Leticia (2011): «El Narciso invertido como metáfora del yo autorreflexivo en tres novelas mexicanas contemporáneas», Relaciones, vol. XXXII, no. 128 , pp. 53-69.

García-Zarranz, Libe (2013): Queer TransCanadian Women's Writing in the 21st Century: Assembling a New Cross-Border Ethic, PhD. Thesis, University of Alberta.

GILroy, Paul (1993): The Black Atlantic: Modernity and Double Consciousness, Harvard UP, Cambridge.

Gordon, Joan, and Veronica Hollinger (1997): «Introduction: The Shape of Vampires», en Joan Gordon and Veronica Hollinger (eds.), Blood Read: The Vampire as Metaphor in Contemporary Culture, University of Pennsylvania Press, Philadelphia, pp. 1-7.

Haraway, Donna (1991): Simians, Cyborgs, and Women: The Reinvention of Nature, Routledge, New York. <https:/ / doi.org/10.4324/9780203873106>

Hernáez LerenA, María Jesús (2019): «Pain and Narrative Shape: Beyond the Indocility of Trauma in Three Newfoundland Novels», Atlantis: Journal of the Spanish Association of Anglo-American Studies, vol. 41, no. 2, pp. 143-160. <https: / / doi. org/10.28914/atlantis-2019-41.2.07>

HeRnÁNDEZ QueSADA, Francisco Javier (2016): «Bestiaria vida: La mirada y crítica del animal», Mitologías hoy: revista de pensamiento, crítica y estudios literarios latinoamericanos, vol. 13, pp. 133-145. <https:/ / doi.org/10.5565/ rev/mitologias.312>

Hernández, Felisberto (2010): Las hortensias y otros relatos (1949), El cuenco de plata, Buenos Aires.

Huggan Graham, and Helen Tiffin (2015): Postcolonial Ecocriticism. Literature, Animals, Environment, Routledge, New York. <https: / / doi.org/10.4324/9781315768342>

JAY, Paul (2010): Global Matters: The Transnational Turn in Literary Studies, Cornell UP, Ithaca, New York. <https: / / doi.org/10.7591/9780801460357>

JoRDAN, Justine (2020): «Tender is the Flesh by Agustina Bazterrica Review», disponible en 
<https: / / www.theguardian.com/books / 2020 / feb / 21 / tender-is-the-fleshagustina-bazterrica-review $>$ [15/03/2019].

LubArsky, Alexander H. (1997): «Argentine 'Dirty War': Human Rights Law and Literature», Theses and Dissertations, Golden Gate University School of Law, San Francisco. 11 April 2018, disponible en https: / digitalcommons.law.ggu.edu/ cgi / viewcontent.cgi?article=1035\&context=theses [12/03/2019].

Llarena Ascanio, María Jesús (2019): «'Another Way of Naming Elsewhere': Transnational and Hemispheric Stories by Some Canadian and Argentinian Authors», Revista Canaria de Estudios Ingleses, vol. 78, pp. 55-73. <http://doi. org.10.25145/j.recaesin.2019.78.004>.

Martín-Lucas, Belén (2012): «Of Aliens, Monsters, and Vampires: Speculative Fantasy's Strategies of Dissent (Transnational Feminist Fiction», en Eva Darias-Beautell (ed.), Unruly Penelopes and the Ghosts, Wilfrid Laurier UP, Waterloo, Ont.

- (2017): «Posthuman Affect in the Global Empire: Queer Speculative Fictions of Canada», en Melissa Tanti, Jeremy Haynes, Daniel Coleman, and Lorraine York (eds.), BEYOND Understanding Canada: Transnational Perspectives on Canadian Literature, University of Alberta Press, Edmonton, pp. 151-171.

McCARTHY, Cormac (2006): The Road, Alfred A. Knopf, New York.

Morales, Ana María (2004): «Lo fantástico en "Las hortensias", de Felisberto Hernández», Escritos. Revista del Centro de Ciencias del Lenguaje, no. 29, pp. 141-156.

MorlA, Jorge (2018): «Samanta Schweblin: “El mal no es la tecnología; es quien está al otro lado"», disponible en <https: / / elpais.com/cultura/2018/10/24/actualidad/1581780901_220507.html>[02/03/2019].

Neuman, Andrés (2005): «La sociedad hispanoamericana y sus proyecciones literarias», II mesa redonda del Instituto Cervantes de Múnich, Renacimiento: Revista de Literatura, vol. 47/50, pp. 132-48.

- (2006): «La narrativa breve argentina desde 1983: ¿hay política después del cuento?», Ínsula: revista de letras y ciencias humanas, vol. 711, pp. 5-11.

- (2014): Una vez Argentina, Penguin Random House, Barcelona.

PigliA, Ricardo (2015): Formas breves, Anagrama, Barcelona.

Poblete, Juan (2018): «Introduction: Twenty-Five Years of Latin American Studies», en New Approaches to Latin American Studies, Routledge, New York, pp. 1-13. $<$ https:/ / doi.org/10.4324/9781315158365-1>

Roas, David (2011): Tras los límites de lo real. Una definición de lo fantástico, Páginas de Espuma, Madrid.

Rodríguez Pappe, Solange (2019): «Pequeñas mujercitas», en Teresa López-Pellisa y Ricard Ruíz Garzón (eds.), Insólitas: Narradoras de lo fantástico en Latinoamérica y España, Páginas de Espuma, Madrid, pp. 99-103.

Schippers, Birgit (2014): The Political Philosophy of Judith Butler, Routledge, London. $<$ https:/ / doi.org/10.4324/9780203551530>

SHILDRICK, Margrit (2001): Embodying the Monster: Encounters with the Vulnerable Self, SAGE Publications, London. <https:/ / doi.org/10.4135/9781446220573>

Schweblin, Samanta (2014): Distancia de rescate, Penguin Random House, Barcelona.

- (2015): Siete casas vacías, Páginas de Espuma, Madrid. 
— (2017): Fever Dream, trans. Megan McDowell, Riverhead Books, New York.

- (2018): Kentukis, Penguin Random House, Barcelona.

- (2020): Little Eyes, trans. Megan McDowell, Oneworld, London.

Siemerling Winfried, and Sarah Phillips Casteel (2010): «Introduction», en W. Siemerling \& S. Phillips Casteel (eds.), Canada and Its Americas: Transnational Navigations, McGill-Queen's UP, Kingston, Montreal, pp. 3-28.

Sugars, Cynthia (2011): «Phantom Nation: English-Canadian Literature and the Desire for Ghosts», Zeitschrift für Kanada-Studien, vol. 31, no. 2, pp. 58-77.

—, and Gerry Turcotte (2009): «Introduction», en C. Sugars and G. Turcotte (eds.), Unsettled Remains: Canadian Literature and the Postcolonial Gothic, Wilfrid Laurier UP, Ontario, pp. VII-XXVI.

—, and Eleanor Ty (2014): «Introduction: Thinking Beyond Nostalgia: Canadian Literature and Cultural Memory», en C.ia Sugars and E. Ty (eds.), Canadian Literature and Cultural Memory, Oxford University Press, pp. 1-19.

Ty, Eleanor (2011): «Representing 'Other' Diasporas in Recent Global Canadian Fiction», College Literature, vol. 8, no. 4, pp. 98-114. <https:/ / doi.org/10.1353/lit. 2011.0047>

Venegas, Socorro (2019): La memoria donde ardía, Páginas de Espuma, Madrid.

Verduyn, Christl (1998): Literary Pluralities, Broadview Press, Ontario.

Winnburst, Shannon (2003): «Vampires, Anxieties, and Dreams: Race and Sex in the Contemporary United States», Hypatia, vol. 18, no. 3, pp. 1-20. <https:/ / doi. org/10.1353/hyp.2003.0070>

Zorc-Maver, Darja and Igor Maver (2011): «Guillermo Verdechia and the frontera in Contemporary Canadian Diasporic Writing», Acta Literaria, vol. 43, pp. 119-126. <https: / doi.org/10.4067/ s0717-68482011000200009> 